name index has been discontinued, and a contents list has been provided at the commencement of each Report. The reviewer regrets the absence of abstracts, but welcomes the announcement that it is proposed to supplement the cumulative name index for Volumes 1-7, already published, by a cumulative index for authors and subject-matter for all the volumes up to date.

S. WEINTROUB

\section{AMERICAN RESOURCES}

Conservation of Natural Resources

Edited by Guy-Harold Smith. Pp. xii +552 . (New York: John Wiley and Sons, Inc.; London : Chapman and Hall, Ltd., 1950.) 48s, net.

"R ESEARCH Conservation" now appears in the curricula of many American universities. It is an indication of the increasing realization that the natural resources of the world in general, and the United States in particular, are far from being inexhaustible, and that serious attention should be paid to their conservation.

The subject as taught in the universities is, in fact, economic geography, dealing in turn with each of the main products required by man, but to which is now added an assessment of reserves and an account of the steps which are taken or should be taken to maintain supplies, so leading into the field of State and local planning.

The book under review deals exclusively with the United States and is the co-operative effort of twenty authors under the general editorship of Prof. Guy Harold Smith, professor of geography in the Ohio State University. It is divided into eight parts, comprising twenty-three chapters. The first chapter, by A. J. Wright (Ohio State University), deals appropriately with the development of conservation in America, and is followed by Chapter 2, "The Public Domain and its Disposal", by S. S. Visher (Indiana University).

Nearly every visitor from the Old World to the New is struck at once by evidences almost everywhere of profligate waste of land and resources. In Britain where the total area of land of all sorts is only a little more than one acre per head of popula. tion, conservation has been automatically a part of the British way of life for many centuries. It is difficult to appreciate what has happened in the United States over the past hundred years, where the exposure of vast tracts of former forest and grassland to the evils of soil erosion by indiscriminate clearing and ploughing has led to the abandonment of millions of acres. It is greatly to be hoped that the evils of the present position there will be fully appreciated before the same forces of destruction are let loose in the so-called under-developed lands of Africa and South America.

Part 2, occupying a major part of the book, deals with soils, soil conservation, tree crops, irrigation, grassland, marsh-reclamation and the agricultural prospect. Part 3 deals with forests, Part 4 with water in its different aspects, Part 5 with minerals, including fuel, Part 6 with wild life and fisheries. Part 7 comprises a chapter on recreational resources and a chapter by the late Ellsworth Huntingdon on the conservation of man and what he called the "geography of the human crop". He draws the conclusion that at present the quality of the American people is declining and that little attention is being paid to the decline. Finally Loyal Durand (Tennessee) deals with State and local planning, and the editor with national planning and the conservation of resources. He rightly stresses the continuing need for research and refers to the United States as a country of diminishing material resources, but where there are still new frontiers to be explored. The United States is passing from the phase of extensive, carefree use of land, to an intensive, careful one.

This volume is a scholarly, objective and timely survey of the whole field; it is fully illustrated by maps and diagrams and adequately documented.

J. Dudlex Stamp

\section{SCIENTIFIC PHOTOGRAPHY}

\section{Wissenschaftliche Photographie}

Eine Einführung in Theorie und Praxis. Von Prof. Dr. E. v. Angerer. Vierte Auflage. Pp. vii +226. (Leipzig: Akademische Verlagsgesellschaft Geest und Portig K.-G., 1950.) 13.80 D. marks.

Photography in Astronomy

By Dr. E. W. H. Selwyn. Pp. 112. (Rochester, N.Y. : Eastman Kodak Company, 1950.) 2.75 dollars. CONSIDERING the wealth of fundamental 4 physical and chemical problems underlying photographic practice, and the many diverse fields of research in which photography is such a valuable - sometimes an indispensable - tool, it is remarkable that there is such a dearth of good general texts on the subject in the English language. In the opinion of the reviewer this is closely connected with the neglect of photography as a subject of study, whether from the scientific interest of its underlying theory or as a branch of technology deserving of scientific analysis, in British universities and higher technical colleges. Certain it is that the position has long been different in Germany and Austria, as the mere mention of such names as Eder, Lüppo-Cramer and Luther will serve to remind us.

The author of "Wissenschaftliche Photographie" is an associate professor at the Technische Hochschule at Munich, and his well-known book (first published in 1939) is a good example of the sort of text we need. Its virtues lie especially in its method of approach to the subject-an approach calculated to appeal to the serious student, and to the research worker who wants something more than a "cookery book' to guide him in his use of photography as a tool. Yet it is not an exhaustive text by any means, but only an introduction to the subject; and for this reason, perhaps, this fourth edition does not differ very markedly from earlier editions. It is excellently produced and moderately priced.

In the absence of academic texts in English, the photographic industry itself has sought in recent years to fill the gap: Dr. C. E. K. Mees's "Theory of the Photographic Process" and Dr. Walter Clark's "Photography by Infra-Red" will come to mind in this connexion. Dr. Selwyn's book on astronomical photography is another excellent, though slender, text from the same source. It is essentially readable, superbly illustrated, and very well produced; and the fact that it comes from one particular industrial company is not obtrusive. The astronomer may find it a useful summary, the student in other fields will certainly learn much from it; but both will no doubt regret its omission of references to original work.

L. V. CHILTON 